\title{
An Empirical Investigation of Foreign and Domestic Portfolio Investment on Economic Growth in Nigeria
}

\author{
Aderoju Bolanle Rahmon \\ Oyo State College of Education, School of Arts and Social Sciences, \\ Department of Economics, P. M. B. 001, Lanlate, Nigeria
}

\begin{abstract}
This paper empirically investigated the growth implications of foreign portfolio investment inflows and foreign portfolio investment outflows in Nigeria over the period 1986 to 2018. Secondary data sourced from the Central Bank of Nigeria (CBN) Statistical Bulletin, National Bureau of Statistics (NBS) and World Development Indicator (WDI) was used for examining the relationships among the endogenous variable and exogenous variables included in the model. The study employed Augumented Dickey Fuller (ADF) unit root test, Phillips-Perron (PP) unit root test, Johansen co-integration test, Ordinary Least Square (OLS) multiple regression technique to investigate the relationships among real gross domestic product (RGDP), foreign portfolio investment outflows (FPI), foreign portfolio investment inflows (DPI), exchange rate (EXGR) and inflation rate (INFR). Empirical findings revealed that foreign portfolio investment inflows (DPI) exerted statistically significant positive relationship with economic growth (RGDP) whereas foreign portfolio investment outflows (FPI) exhibited statistically significant negative relationship with economic growth (RGDP) in Nigeria over the studied period. Based on the estimated results, government at all levels in Nigeria should create enabling environment for the attraction of foreign portfolio investment inflows in order to spur economic growth; and monetary authorities in Nigeria should ensure stabilization of capital and money market activities with appropriate policies to sustain internalization and attractiveness to investors.
\end{abstract}

Keywords: Foreign portfolio investment outflows, Domestic portfolio investment inflows, Economic growth, Ordinary Least Square Regression, Nigeria

DOI: $10.7176 / \mathrm{JESD} / 13-2-02$

Publication date: January $31^{\text {st }} 2022$

\section{Introduction}

All economies of the world consider the inflows and outflows of capital especially private capital as one of the major factors or instruments essential for rapid economic growth and development of their respective countries. In financial economics literature, foreign investments can be attracted into an economy through two major channels namely foreign direct investments (FDI) which involves direct ownership of business entities in foreign countries and foreign portfolio investments (FPI) which refers to investing in the securities and other financial assets of a foreign country such as stocks, bonds, mutual funds, exchange traded funds, American depository receipts (ADR) and global depository receipts (GDR). Foreign portfolio investment inflows and foreign portfolio investment outflows are seen by both advanced economies and developing countries of the world as valuable sources of finance and capital formation. These two types of investment play significant role to developing economies or underdeveloped countries in that it increases capital accumulation for production activities, technology transfer and know-how, improvement of balance of payments, creation of business opportunities and generation of huge revenue via taxation by governments. Furthermore, foreign portfolio investment influences economic performance of recipient nations in terms of employment generation, increased productive activities, income distribution, poverty reduction and domestic investment enhancement. Several empirical studies have been conducted on the effects of foreign direct investment on economic growth in Nigeria by different researchers owing to availability of data on their interested economic variables. But few studies exist relating to the nexus between foreign portfolio investment (inflows and outflows) and economic performance in Nigeria due to paucity of data on related economic variables.

Nigeria, the giant of Africa population-wise, has formulated various economic policies aimed at promoting economic growth through the stimulation of domestic production activities. The economy needs substantial amount of capital from advanced economies of the world where surplus funds are available. This necessitated the attraction of foreign portfolio investment by Nigerian government at various levels to fill the saving-investment gaps due to low rate of capital accumulation and poverty in order to promote sustainable economic growth and development. According to Central Bank of Nigeria Statistical Bulletin (2020) and World Development Indicator (2020), the value of foreign portfolio investment inflows in Nigeria in 1986 was \#86633232.88 million while foreign portfolio investment outflows stood at \#151.6 million. In 1990, foreign portfolio investment inflows increased to \#197148078.85 million whereas foreign portfolio investment outflows rose to \#435.2 million. These figures rose to $\# 502264890.6$ million and $\# 51079.1$ million in 2000. In 2006, foreign portfolio investment inflow skyrocketed to \#1244628.18million while foreign portfolio investment outflow was \#557873.68 million. In 2010, 
foreign portfolio investment inflow and outflow figures were \#2094331.92 million and \#222244.45 million respectively. The figure for foreign portfolio investment inflow was \#1892402.59 while that of foreign portfolio investment outflow stood at \#289185.30 in 2015. These figures escalated to \#7763252.45 million and \#458894.23 million in 2018 respectively.

Despite the colossal amount of inflows of foreign capital to Nigerian economy and the outflows of domestic capital to foreign economies, the impact of these movements of capital on economic growth in Nigeria needs to be ascertained or investigated so that appropriate policies should be formulated by the federal government and sub-national governments to make these investments beneficial to the Nigerian populace. This study intends to fill the lacuna in the literature by providing answers to the following questions: What is the relationship between foreign portfolio investment inflows and economic growth in Nigeria? What nexus exists between foreign portfolio investment outflows and economic growth in Nigeria? Does exchange rate exert statistically significant positive relationship with economic growth in Nigeria?

\section{Objectives of the Study}

The general objective of the study is to investigate the effect of foreign and domestic portfolio investment on economic growth in Nigeria over the period 1986 to 2018. The specific objectives are to: --examine the impact of foreign portfolio investment inflow on economic growth in Nigeria. -analyze the relationship between domestic portfolio investment outflow and economic growth in Nigeria. - recommend appropriate policy measures to improve the contributions of foreign portfolio investment inflow and domestic portfolio investment outflow to economic growth in Nigeria based on the estimated results.

\section{Hypotheses of the Study}

1. $\mathrm{H}_{0}$ : Foreign portfolio investment inflows have no statistically significant positive relationship with economic growth in Nigeria.

2. $\mathrm{H}_{0}$ : Domestic portfolio investment outflows have no statistically significant positive connection with economic growth in Nigeria.

\section{Review of Related Literature}

Several studies have been conducted on the relationship between foreign portfolio investment and economic growth in both advanced economies and developing countries of the world. Existing studies on the relationship among domestic portfolio investment, foreign portfolio investment and economic growth for Nigeria are very scanty. Below are some of the findings of previous studies conducted on the nexus among foreign portfolio investment, domestic investment and economic growth. Gini (2021) empirically examined the effect of interest rate on portfolio investment in Nigeria from 1984 to 2018. Secondary data sourced from Central Bank of Nigeria $(\mathrm{CBN})$ statistical bulletin and World Development Indicator (WDI) was used for the study. Autoregressive Distributed Lag Model (ARDL) estimating technique was employed for the analysis of the endogenous and exogenous variables in the model. The findings showed that interest rate has a positive and significant effect on portfolio investment in the short run but no effect in the long run. It was concluded that apart from interest rate, factors affecting portfolio investment in Nigeria is multi-dimensional. The study recommended that the Central Bank of Nigeria $(\mathrm{CBN})$ should consider an interest rate threshold that applies to both lenders and borrowers so that none get worse off, so as to promote positive portfolio investment and economic growth.

Ndugbu, Otiwu\&Uzowuru (2021) examined the relationship between foreign portfolio investment and economic growth in Nigeria between the periods 1986 to 2017. Secondary data consisting of time series and panel data were sourced and extracted from Central Bank of Nigeria (CBN) Statistical Bulletin, Central Bank of Nigeria (CBN) Annual Report and Statement of Account, Central Bank of Nigeria Bullion, journals and internet sources. The study employed the Vector Error Correction Model (ECM) for estimation. Market capitalization, foreign portfolio investment and trade openness were the exogenous variables while real gross domestic product proxy for economic growth was the endogenous variable. Empirical findings revealed that of the three studied variables, trade openness and market capitalization proved to be statistically significant in promoting economic growth in Nigeria while foreign portfolio investment is negative and insignificant. The study recommended that policy makers should endeavor to boost the capital market activities so as to foster capital transactions and subsequently increase economic performance and growth in the nation. Adofu\&Adegoriola (2020) investigated the relationship between foreign portfolio investment and economic growth in Nigeria from 1986 to 2018. Annual time series data sourced from Central Bank of Nigeria (CBN) Statistical Bulletin and National Bureau of Statistics (NBS) were used for the study. The methodology employed for the analysis was Autoregressive Distributed Lag (ARDL) model. Evidence from results showed that current value and one period lag of Foreign Portfolio Investment (FPI) showed negative and insignificant impacts on the Gross Domestic Product (GDP). There is unidirectional causality between gross domestic product and foreign portfolio investment. The causality flows from gross domestic product to foreign portfolio investment. The study, therefore, recommended that government should double its effort at 
improving the investment. The government should support the prevailing investors through improvement in infrastructural development.

Otapo\&Adekunle (2021) empirically examined the dynamic effects of foreign portfolio investment on economic growth in Nigeria over the period 1980 to 2018. Time series data extracted from the Central Bank of Nigeria Statistical Bulletin were used for the study. Augumented Dickey Fuller (ADF) unit root test, Bound Cointegration test and Autoregressive Distributed Lag (ARDL) model were employed for the estimation of the model. The study specified economic growth proxy by real gross domestic product as endogenous variable while domestic savings, government capital expenditures and market capitalization were the exogenous variables. The results of empirical estimations in the short term showed that domestic savings had significant and negative impact on gross domestic product. The study empirically confirms and theoretically proves that foreign investment, domestic savings, government spending and market capitalization determine long term trends in gross domestic product formation in Nigeria. The empirical result revealed that the presence of a significant deficit of domestic savings in Nigeria creates obstacles to successful economic growth in the country both in short and long term. Portfolio foreign investment accelerates economic growth in the long run to a greater extent than in the short run.

Misbah, Muhammad, Aysha\& Malik (2021) investigated the nexus between economic growth and foreign private investment in Pakistan over the period 1996 and 2017. The study utilized time series data for examining the relationships among economic growth, taxes, technology, trade openness and exchange rate on the sustainability of foreign private investment in Pakistan. Random effects and generalized squares estimators were employed for estimating the model. The results indicated that the Pakistan economy has been positively influenced regarding the location and choice of emerging and developed countries' investment in the domestic market. Acha\&Essien (2018) examined the effect of portfolio investment on economic growth in Nigeria for the period 2005 to 2014. Secondary data sourced from the Central Bank of Nigeria Statistical Bulletin were used for the study. Gross Domestic Product was used as the dependent variable while foreign portfolio investment, market capitalization as well as exchange rate were the independent variables. Ordinary Least Square (OLS) multiple regression was used to analyze the data. Empirical findings revealed that foreign portfolio investment and market capitalization have positive effect on real gross domestic product while exchange rate had an inverse relationship with real gross domestic product. The study recommended that since economic performance is critical to attracting foreign portfolio investment into any country, the federal government of Nigeria should create enabling environment that will stimulate the economy and strengthen its fundamentals. The government should also work towards the stabilization of the capital and money markets by putting in place appropriate investor friendly policies to sustain their internalization and attractiveness to investors.

Lyndon \&Ayaundu (2020) empirically evaluated the effect of foreign investment inflows on economic growth in Nigeria using secondary data for the period 2001 to 2018. The study adopted gross domestic product as the indicator of economic growth and the dependent variable, while foreign direct investment, foreign portfolio investment and exchange rate were used as explanatory variables. Secondary data extracted from the Central Bank of Nigeria Statistical Bulletin were used for the study. The study employed descriptive statistics and multiple regression analysis technique based on the E-view computer software for analyzing data. Empirical findings revealed that foreign direct investment, foreign portfolio investment and exchange rate had significant positive influence on gross domestic product in Nigeria. The study recommended that the regulatory authorities should formulate policies and create the enabling environment to attract foreign investments into Nigeria. Akinbobola, Ibrahim \& Ibrahim (2017) investigated the effect of foreign portfolio investment on economic growth in Nigeria from 1986 to 2013. Secondary data obtained from Central Bank of Nigeria Statistical Bulletin and National Bureau of Statistics was utilized for the study. Augumented Dickey Fuller unit root test, Phillips Perron unit root test, Johansen Co-integration and Toda and Yamamoto Causality Technique were employed for estimating the parameters of the model. Empirical findings from the study revealed that foreign portfolio investment and economic growths are positively co-integrated indicating a stable long run equilibrium relationship. The results further showed that there is bidirectional causality between foreign portfolio investment and economic growth and the complementary role of domestic savings and interest rate in growth.

Ezeanyeji\&Ifeako (2019) examined the effect of foreign portfolio investment on economic growth in Nigeria from 1986 to 2017. Secondary data sourced from Central Bank of Nigeria Statistical Bulletin and National Bureau of Statistics was used for the study. Error Correction Mechanism technique was employed for analyzing the dependent variable and independent variables included in the model. The variables analyzed are real gross domestic product, net foreign portfolio investment, inflation rate, market capitalization and trade openness. Empirical findings revealed that foreign portfolio investments have statistically significant positive relationship with economic growth in Nigeria. The study recommended that government should initiate policies which will spur long -run growth of the capital market and therefore the economy at large. Muhammad, Muhammad, Shamila\&Shujahat (2017) investigated the impact of stock market performance on foreign portfolio investment in china. Quarterly time series data from 2007 to 2015 were used for the study. The estimating technique utilized was the autoregressive distributed lag model in analyzing the impact of the explanatory variables on the explained 
variable. Empirical findings from the study revealed that stock market performance has significant positive impact on foreign portfolio investment, whereas inflation was negatively associated with foreign portfolio investment. The study further showed that historical events, such as Asian financial crisis of 2008 and the Shanghai composite stock index of 2015 significantly affected foreign portfolio investment in China.

Iriobe, Obamuyi\&Abayomi (2018) empirically analyzed the effect of foreign portfolio equity investment on stock market performance in Nigeria from 2007 to 2017. The study employed secondary data obtained from Central Bank of Nigeria Statistical Bulletin and National Bureau of Statistics. Autoregressive Distributed Lag (ARDL) model was used in analyzing the data. Empirical findings revealed that there exists a significant difference in the sectoral distribution of foreign portfolio investment inflows to the Nigerian economy. The result further showed that foreign portfolio equity investment exerted a significant positive influence on the Nigerian stock exchange performance. The study recommended that the regulatory authorities should deepen the equity stocks of the market and encourage more firms to get listed on the Nigerian Stock Exchange with a view to channeling more investments into the economy thereby fast-tracking industrialization and economic development. Akinmulegun (2018) examined the effect of capital market development on foreign portfolio investment in Nigeria over the period 1985 to 2016. Time series data sourced from Central Bank of Nigeria Statistical Bulletin and National Bureau of Statistics were used for the study. Vector Error Correction Mechanism (VECM) was employed to analyze the short run and long run dynamism of the variables while also focusing on the direction of causality between capital market development and foreign portfolio investment in Nigeria, using granger causality test. Empirical results from the Vector Error Correction Model indicated that market capitalization has significant negative on foreign portfolio investment in Nigeria while All Share Index has significant positive relationship with foreign portfolio investment. The study recommended that government should develop and enforce policies that will further propel capital market development in order to sustain its positive effect in attracting foreign portfolio into the Nigerian economy as well as stimulate improved interest of foreign investors in subscribing to portfolio investment in Nigerian Enterprises.

Makoni\&Marozva (2018) examined the nexus between foreign portfolio investment and financial market development in Mauritius for the period 1989 to 2016. The study employed Autoregressive Distributed Lag model, Vector Error Correction Mechanism and Granger causality methodologies to access the relationships among the included variables in the model. Empirical findings showed co-integrating relationships between foreign portfolio investment (FPI) and foreign direct investment (FDI), financial market development (FMD) and real economic growth (RGDP). The vector error correction model further confirmed the existence of long run relationships among the variables under observation. Short run causality was found to emanate from FPI, FDI and RGDP to FMD. Granger causality result confirmed that FMD causes both FPI and FDI, while FPI caused FDI. Moreover, jointly FDI, FMD and GDP growth collectively cause FPI. The results of the study found no causality running from FPI, FDI and RGDP to FMD, implying that financial market development in Mauritius is internally catalyzed. Mugableh\&Oudat (2018) empirically investigated the determinants of foreign portfolio investments and causality analysis for Jordan. The study examined the effect of domestic market capitalization, foreign direct investment, money supply and government expenditures on foreign portfolio investments. The co-integration test showed the existence of co-integration foreign portfolio investments and their determinants. Granger causality based on Vector Error Correction Mechanism (VECM) showed bidirectional causality among the variables in the long run and the short run. Autoregressive Distributed Lag (ARDL) bonds testing approach was used for estimating the parameters of the model. All the exogenous variables have positive impact on foreign portfolio investments both in the long run and short run. The study recommended that policy makers in the government of Jordan should regularly review economic and financial policies and pay high attention towards the rights of foreign investors. There should also exist political stability and sound economic policies capable of attracting foreign investments and economic prosperity to Jordan.

Tsaurai (2017) assessed the impact of foreign portfolio equity investments on economic growth in Asian and European and emerging markets. The study utilized panel data of fourteen Asian and European emerging markets for the period 2001 to 2014. Generalized Methods of Moments (GMM) was used in order to cater for the dynamic nature of economic growth data and the possible endogeneity problem that exists between foreign portfolio investments and economic growth. Empirical findings revealed that foreign portfolio equity investments positively but not significantly influenced economic growth in both Asian and European emerging markets. The study therefore recommended that Asian and European emerging markets to speed up the implementation of foreign portfolio investment enhancement policies and initiatives in order to guarantee long term positive growth of their economies. Those economies should target both foreign portfolio equity investments and foreign portfolio bonds investments in order to foster long term positive and significant economic growth. OnyeisiOdo\&Anoke (2016) empirically investigated the impact of foreign portfolio investment inflows on stock exchange growth in Nigeria from 1986 to 2014. Secondary data sourced from Central Bank of Nigeria Statistical Bulletin and National Bureau of Statistics was used for the study. Co-integration test, vector error correction mechanism and granger causality econometric analytical methods were employed to analyze the endogenous and exogenous variables in the model. 
Empirical results found that there exists co-integration between foreign portfolio investment and stock exchange growth while foreign portfolio investment has significant long run impact on stock exchange growth in Nigeria within the period of the study. The result further showed that there is no causality between foreign portfolio investment and stock market in Nigeria. The study therefore recommended that federal government should strengthen the security exchange commission so as to stimulate constant inflow of foreign portfolio investment to Nigerian economy.

Osmond (2016) examined the effect of foreign portfolio investment on industrial growth in Nigeria from 1986 to 2013. Secondary data sourced from Central Bank of Nigeria Statistical Bulletin was used for the study. Ordinary Least Square (OLS) estimation technique was employed in analyzing the relationship among the included variables. Empirical findings from the study revealed that there is statistically significant positive relationship among foreign portfolio investment, gross fixed capital formation, market capitalization and industrial growth in Nigeria. The study therefore recommended that market capitalization should be expanded in order to stimulate industrial productivity in Nigeria. Okafor, Ezeaku\&Eje (2015) examined the effect of foreign investments disaggregated into foreign direct investment and foreign portfolio investment inflows on economic growth in Nigeria with a view to ascertaining the higher contributor, using time series data from 1987 to 2012 . The methodology used in analyzing the data included the Ordinary Least Square multiple regression technique and the Granger causality procedures. Empirical findings revealed that both foreign direct investment and foreign portfolio investment have positive and significant impact on economic growth though the correlation coefficients showed that foreign portfolio investment is the better contributor. The study recommended that government should pursue policies that encourage both foreign direct investment and foreign portfolio investment.

\section{Conceptual Framework}

Economic Growth- Economic growth can be defined as the sustained increase in the capacity of an economy to produce goods and services, compared from one period of time to another. It can be measured in nominal or real terms, the latter of which is adjusted for inflation. Traditionally, aggregate economic growth is measured in terms of gross domestic product (GDP). Economic growth usually occurs whenever people take resources and rearrange them in ways that are more valuable. It is proxied by real gross domestic product. This is the dependent variable or endogenous variable whose behavior is influenced or determined by a set of exogenous or explanatory variables in the model namely foreign portfolio investment inflow (FPI), foreign portfolio investment outflow (DPI), exchange rate (EXGR) and inflation rate (INFR). This variable can also be referred to as controlled or outcome or regressand.

Foreign Portfolio Investment Inflow- This exogenous variable refers to the inward movement of foreign capital into the domestic economy through the purchase of securities and other domestic financial assets by foreign investors. The portfolio investment made by domestic investors is also included in the determination of its value. Theoretically, this variable is expected to exert a significant positive influence on economic growth proxy by real gross domestic product. The more an economy enjoys inward movement of capital from foreign economies via portfolio investment, the higher will be the rate of its economic growth while the converse is true

Foreign Portfolio Investment Outflow- This explanatory variable connotes the outward movement of domestic capital to foreign economies through the procurement of foreign securities and other foreign financial assets by domestic investors. It is expected to influence economic growth positively because the profits made by domestic investors from foreign portfolio investments would be used for productive activities in the domestic economy thereby increasing gross domestic product or economic growth. This could also translate to favorable balance of payment for the domestic economy through escalation of sectorial output of goods.

Exchange Rate- Exchange rate is the price of one currency in terms of another currency. In financial economics literature, an exchange rate or forex rate between two currencies is the rate at which one currency will be exchanged for another. Exchange rates are determined in the foreign exchange market, which is open to a wide range of buyers and sellers where currency trading is continuous. This covariate variable is expected to exert negative impact on economic growth due to deteriorating value of the naira against the dollar and other foreign currencies.

Inflation Rate-Inflation rate is the rate at which the value of a currency is falling or declining and consequently, the general level of prices for goods and services is rising. The most commonly used inflation indexes are the Consumer Price Index (CPI) and the Wholesale Price Index (WPI). Prices of goods and services in Nigeria have been skyrocketing over the years which would have adverse effect on productive activities in the economy. Inflation rate is expected to exert statistically significant negative impact on productive activities in Nigeria.

\section{Data and Methodology}

This study investigated the effect of foreign portfolio investment inflows or domestic portfolio investment (DPI) and foreign portfolio investment outflows (FPI) on economic growth in Nigeria for the period 1986 to 2018 using secondary data sourced from the Central Bank of Nigeria (CBN) Statistical Bulletin of various editions and World Bank Development Indicator (WDI) database. These sources of data were considered reliable for the variables 
adopted for the study namely real gross domestic product (proxy for economic growth) as the endogenous variable, while foreign portfolio investment inflows (DPI), foreign portfolio investment outflows (FPI), exchange rate (EXGR) and inflation rate (INFR) as exogenous variables.

\section{Model Specification}

A multivariate linear regression model was adopted to test each of the null hypotheses proposed for the study. Based on the formulated hypotheses, the functional relationship between the functional relationship between the dependent variable and the explanatory variables was stated as specified below:

RGDP $=$ F( DPI, FPI, EXGR, INFR)

The above mathematical form of the model was transformed into a functional econometric equation as follows: $\mathrm{RGDP}=\mathrm{b}_{0}+\mathrm{b}_{1} \mathrm{DPI}+\mathrm{b}_{2} \mathrm{FPI}+\mathrm{b}_{3} \mathrm{EXGR}+\mathrm{b}_{4} \mathrm{INFR}+\mathrm{U}$

where

RGDP=Real gross domestic product

DPI $=$ Domestic portfolio investment inflows

FPI $=$ Foreign portfolio investment outflows

$\mathrm{EXGR}=$ Exchange rate

INFR $=$ Inflation rate

$\mathrm{b}_{0}=$ Intercept or constant

$\mathrm{b}_{1}, \mathrm{~b}_{2}, \mathrm{~b}_{3} \& \mathrm{~b}_{4}=$ Elasticity of the parameters of the explanatory variables

$\mathrm{U}=\mathrm{Random}$ term or error term of the equation

The study employed multiple regression analysis technique based on the Ordinary Least Square (OLS), Augumented Dickey Fuller (ADF) unit root test, Phillips-Perron (PP) unit root test and Johansen Co-integration test to examine the relationships among economic growth, foreign portfolio investment inflows, foreign portfolio investment outflows in Nigeria over the period 1986 to 2018.

Stationary Test

Table 1 Augumented Dickey Fuller Statistics of the Variables

\begin{tabular}{|c|c|c|c|c|c|c|}
\hline Variables & $\begin{array}{c}\text { ADF } \\
\text { Statistics }\end{array}$ & $\mathbf{1 \%}$ & $\mathbf{5 \%}$ & $\mathbf{1 0 \%}$ & $\begin{array}{c}\text { Order of } \\
\text { Integration }\end{array}$ & $\begin{array}{c}\text { Maximum } \\
\text { No of Lag }\end{array}$ \\
\hline DPI & -4.357541 & -2.639201 & -1.951687 & -1.610579 & $\mathrm{I}(0)$ & 9 \\
\hline EXGR & -3.417051 & -2.641672 & -1.952066 & -1.610400 & $\mathrm{I}(1)$ & 9 \\
\hline FPI & -9.327371 & -3.661661 & -2.960411 & -2.619160 & $\mathrm{I}(0)$ & 9 \\
\hline INFR & -4.966873 & -3.661661 & -2.960411 & -2.619160 & $\mathrm{I}(1)$ & 9 \\
\hline RGDP & -7.218388 & -3.670170 & $-2,963972$ & $-2,621007$ & $\mathrm{I}(1)$ & 9 \\
\hline
\end{tabular}

Source: Author's Computation using E-view 9

Table 2 Phillips-Perron Statistics of the Variables

\begin{tabular}{|c|c|r|r|r|c|c|}
\hline Variables & PP Statistics & $\mathbf{1 \%}$ & $\mathbf{5 \%}$ & $\mathbf{1 0 \%}$ & $\begin{array}{c}\text { Order of } \\
\text { Integration }\end{array}$ & $\begin{array}{c}\text { Maximum } \\
\text { No of Lag }\end{array}$ \\
\hline DPI & -4.246920 & -2.639210 & -1.951687 & -1.610579 & $\mathrm{I}(0)$ & 9 \\
\hline EXGR & -3.412758 & -2.641672 & -1.952066 & -1.610400 & $\mathrm{I}(1)$ & 9 \\
\hline FPI & -5.659661 & -3.653730 & -2.957110 & -2.617434 & $\mathrm{I}(0)$ & 9 \\
\hline INFR & -7.630662 & -2.641672 & -1.952066 & -1.610400 & $\mathrm{I}(1)$ & 9 \\
\hline RGDP & -9.408291 & -3.670170 & -2.963972 & -2.621007 & $\mathrm{I}(1)$ & 9 \\
\hline
\end{tabular}

Source: Author's Computation using E-view 9

Time series data are mostly not stationary, implying that, its mean, variance and covariance are time variant. Econometricians are faced with non-stationary series since it prompts to spurious regression outcomes. Therefore, it is necessary to conduct stationary test for all the variables to verify the asymptotic of the series. Stationarity test helps the econometrician to determine the order of integration of the series under investigation. The implication of a spurious regression is a data set with no explanatory power and policy strength. It can be seen from tables $1 \& 2$ above that some of the variables are stationary at their levels while others become stationary after taking their first differences. Following these unit root tests, the Johansen Co-integration test is employed to examine the presence of any long-run association among the variables. 


\section{Table 3}

Date: 12/27/21 Time: 01:27

Sample (adjusted): 19882018

Included observations: 31 after adjustments

Trend assumption: No deterministic trend

Series: RGDP FPI DPI EXGR INFR

Lags interval (in first differences): 1 to 1

Unrestricted Cointegration Rank Test (Trace)

\begin{tabular}{|c|c|c|c|c|}
\hline $\begin{array}{l}\text { Hypothesized } \\
\text { No. of CE(s) }\end{array}$ & Eigenvalue & $\begin{array}{c}\text { Trace } \\
\text { Statistic }\end{array}$ & $\begin{array}{c}0.05 \\
\text { Critical Value }\end{array}$ & Prob.** \\
\hline None * & 0.775292 & 93.65929 & 60.06141 & 0.0000 \\
\hline At most $1 *$ & 0.568844 & 47.37772 & 40.17493 & 0.0081 \\
\hline At most 2 & 0.432829 & 28.29784 & 24.27596 & 0.0034 \\
\hline At most 3 & 0.112940 & 3.717930 & 12.32090 & 0.7512 \\
\hline At most 4 & $9.00 \mathrm{E}-05$ & 0.002791 & 4.129906 & 0.9642 \\
\hline
\end{tabular}

Trace test indicates 3 cointegratingeqn(s) at the 0.05 level

* denotes rejection of the hypothesis at the 0.05 level

**MacKinnon-Haug-Michelis (1999) p-values

Unrestricted Cointegration Rank Test (Maximum Eigenvalue)

\begin{tabular}{|c|c|c|c|c|}
\hline $\begin{array}{l}\text { Hypothesized } \\
\text { No. of CE(s) }\end{array}$ & Eigenvalue & $\begin{array}{c}\text { Max-Eigen } \\
\text { Statistic }\end{array}$ & $\begin{array}{c}0.05 \\
\text { Critical Value }\end{array}$ & Prob.** \\
\hline None $*$ & 0.775292 & 46.28158 & 30.43961 & 0.0003 \\
\hline At most $1 *$ & 0.568844 & 26.07988 & 24.15921 & 0.0272 \\
\hline At most 2 & 0.432829 & 19.57991 & 17.79730 & 0.0038 \\
\hline At most 3 & 0.112940 & 3.715139 & 11.22480 & 0.6741 \\
\hline At most 4 & $9.00 \mathrm{E}-05$ & 0.002791 & 4.129906 & 0.9642 \\
\hline
\end{tabular}

Max-eigenvalue test indicates 3 cointegratingeqn(s) at the 0.05 level

* denotes rejection of the hypothesis at the 0.05 level

**MacKinnon-Haug-Michelis (1999) p-values

From the Johansen Co-integration test table presented above, it is obvious that the variables in the equation are co-integrated. The existence of three co-integration equations suggests that there is a long run relationship among the variables in the equation. Trace test and Max-Eigen statistic indicate three co-integration equations at $5 \%$ level of significance respectively. Consequently, an ordinary least square regression was estimated because some of the variables are stationary at levels and others at their various first differences. 
Table 4

Dependent Variable: RGDP

Method: Least Squares

Date: 12/26/21 Time: 19:24

Sample: 19862018

Included observations: 33

\begin{tabular}{|c|c|c|c|c|}
\hline Variable & Coefficient & Std. Error & t-Statistic & Prob. \\
\hline $\mathrm{C}$ & 19602.16 & 3345.560 & 5.859157 & 0.0000 \\
\hline FPI & -0.190468 & 0.173211 & -1.099630 & 0.2809 \\
\hline DPI & 7.900248 & 6.767930 & 1.167306 & 0.0529 \\
\hline EXGR & 194.3108 & 18.10184 & 10.73432 & 0.0000 \\
\hline INFR & -34.76545 & 85.97253 & -0.404379 & 0.6890 \\
\hline R-squared & 0.842716 & Mean dependent var & & 38148.90 \\
\hline Adjusted R-squared & 0.820247 & S.D. dependent var & & 18804.78 \\
\hline S.E. of regression & 7972.719 & Akaike info criterion & & 20.94417 \\
\hline Sum squared resid & $1.78 \mathrm{E}+09$ & Schwarz criterion & & 21.17091 \\
\hline Log likelihood & -340.5787 & Hannan-Quinn criter. & & 21.02046 \\
\hline F-statistic & 37.50550 & Durbin-Watson stat & & 1.931059 \\
\hline Prob(F-statistic) & 0.000000 & & & \\
\hline
\end{tabular}

Table 5 Presentation of Regression Result Dependent Variable: RGDP Sample: 1986-2018

\begin{tabular}{|l|l|l|l|l|}
\hline Variables & $\begin{array}{l}\text { Estimated } \\
\text { Coefficient }\end{array}$ & T-Value & $\begin{array}{l}\text { Apriori } \\
\text { Expectation }\end{array}$ & Inference \\
\hline Constant term & 19602.16 & 5.859157 & $\mathrm{~b}_{0}>0$ & Correct sign and significant \\
\hline FPI & -0.190468 & -1.099630 & $\mathrm{~b}_{1}>0$ & Incorrect sign and significant \\
\hline DPI & 7.900248 & 1.167306 & $\mathrm{~b}_{2}>0$ & Correct sign and significant \\
\hline EXGR & 194.3108 & 10.73432 & $\mathrm{~b}_{3}<0$ & Incorrect sign and significant \\
\hline INFR & -34.76545 & -0.404379 & $\mathrm{~b}_{4}<0$ & Correct sign and significant \\
\hline Significant at 5\% & & $\mathrm{R}^{2}=0.84$ & & DW 1.9 \\
\hline
\end{tabular}

\section{Discussion of Empirical Findings}

From Table 4 above, foreign portfolio investment inflows (DPI) and exchange rate (EXGR) are positively related to real gross domestic product (RGDP) with coefficients of 7.900248 and 194.3108 respectively. This implies that a one unit change in foreign portfolio investment inflows and exchange rate would bring about 7.900248 and 194.3108 increasses in real gross domestic product during the studied period. On the other hand, foreign portfolio investment outflows (FPI) and inflation rate (INFR) have negative relationships with economic growth proxied by real gross domestic product with coefficients of -0.190468 and -34.76545 . This can be interpreted to mean that a one unit change in foreign portfolio investment outflows and inflation rate would bring about -0.190468 and 34.76545 decreases in real gross domestic product. From table 4, the econometric regression equation (2) consisting of an endogenous variable and a set of exogenous variables can be re-stated as specified below:

$\mathrm{RGDP}=19602.16-0.19068 \mathrm{FPI}+7.900248 \mathrm{DPI}+194.3108 \mathrm{EXGR}-34.76545 \mathrm{INFR}$.

Overall, the results show r-squared of 0.842716 and adjusted r-squared of 0.820247 indicated that about 84.3 percent of changes in the dependent variable (real gross domestic product) were accounted for by the combined changes in the explanatory variables; and the researcher can state with $82 \%$ confidence that the regression model is a good and proper fit. That is, the explanatory variables are useful in predicting changes in the dependent variable. Furthermore, F-statistic is 37.50550 with a probability of 0.000000 , which is significant at 5 percent, indicating that the explanatory variables, taken together, have a significant impact on economic growth in Nigeria. The value of the Durbin-Watson statistic is 1.931059 . This falls within the determinate region and this connotes that the model is free from autocorrelation problem.

\section{Test of Hypotheses}

Hypothesis 1 (DPI and RGDP)

Foreign portfolio investment inflows have no statistically significant positive impact on real gross domestic product in Nigeria. From Table 4, foreign portfolio investment inflows have a t-statistic of 1.167306 with a probability value of 0.0529 , which is approximately 0.05 , meaning that DPI has significant positive effect on 
RGDP. The null hypothesis is therefore rejected. The study concludes that foreign portfolio investment inflows have statistically significant positive impact on economic growth in Nigeria.

Hypothesis 2 (FPI and RGDP)

Foreign portfolio investment outflows have no statistically significant positive connection with real gross domestic product in Nigeria. Again, from Table 4, foreign portfolio investment outflows have a t-statistic of -1.099630 with a probability value of 0.2809 , which is higher than 0.05 , meaning that FPI have no statistically significant positive connection with RGDP. The null hypothesis is therefore rejected. The study concludes that foreign portfolio investment outflows have no statistically significant positive impact on the growth of the Nigerian economy.

\section{Conclusion and Recommendations}

This study investigated the effect of foreign portfolio investment inflows (DPI) and foreign portfolio investment outflows (FPI) on economic growth of Nigeria using secondary data sourced from the Central Bank of Nigeria (CBN) Statistical Bulletin of various editions and World Development Indicator (WDI) Database for the period 1986 to 2018. The study adopted real gross domestic product as the indicator of economic growth and endogenous variable, while foreign portfolio investment inflows, foreign portfolio investment outflows, exchange rate and inflation rate were used as exogenous variables. The study employed multiple regression analysis technique based on the E-view 9 computer software for analyzing the data. Empirical findings revealed that foreign portfolio investment inflows and exchange rate had statistically significant positive impact on real gross domestic product while foreign portfolio investment outflows exerted statistically significant negative effect on real gross domestic product during the studied period.

Based on the estimated results, the following recommendations are made:

Government at all levels in Nigeria should create enabling environment for the attraction of foreign portfolio investment inflows in order to spur economic growth.

-Monetary authorities in Nigeria should ensure stabilization of capital and money market activities with appropriate policies to sustain internalization and attractiveness to investors.

-Drastic measures should be taken by the government to ensure exchange rate stability and low inflation rate.

\section{References}

Acha, I. A. \&Essien, J. M. (2018).The economic growth imperative of foreign portfolio investment for Nigeria.Noble International Journal of Economics and Financial Research, 3(6), 71-77.

Adofu, I. \&Adegoriola, A. E. (2020).Freign portfolio investment and economic growth in Nigeria (19862018).NigerrianDefence Academy Journal of Economics and Finance, 4(1), 195-202.

Akinbobola, T., Ibrahim, R. \& Ibrahim, O. (2017). Foreign portfolio investment-economic growth nexus in Nigeria: Co-integration and granger causality analyses. Research Journal of Finance and Accounting, 8(5), 11-17.

Akinmulegun, S. O. (2018). Capital market development and foreign portfolio investment inflow in Nigeria (19852016). Advances inEconomics and Business, 6(5), 299-307.

Central Bank of Nigeria Statistical Bulletin (2020).

Ezeanyeji, C. I. \& Maureen, I. (2019). Foreign portfolio investment and economic growth of Nigeria: An impact analysis. International Journal of Academic Management Science Research,3(3), 24-36.

Gini, K. B., Akokaike, M. N. (2021). Interest rate and portfolio investment in Nigeria.Global Scientific Journal, 9(9), 83-106.

Iriobe, G. O., Obamuyi, T. M. \&Abayomi, M. A. (2018).Foreign portfolio equity investment and the performance of the Nigerian stock market.International Business and Management, 16(1), 29-38.

Makoni, P. L. \&Marozva, G. (2018). The nexus between foreign portfolio investment and financial market development: Evidence from Mauritius. Academy of Strategic Management Journal, 17(5), 1-14.

Misbah, S., Muhammad, U., Aysha, Z., Malik, S. S. \&Ankasha, A. (2021). Nexus between economic growth and foreign private investment: Evidence from Pakistan economy. Cogent Economics and Finance, 9(1), 1-59.

Mugableh, M. I. \&Oudat, M. S. (2018). Modelling the determinants of foreign portfolio investments: A bounds testing and causality analysis for Jordan.Academic of Accounting and Financial Studies Journal, 22(4), 1-8.

Ndugbu, M. O., Otiwu, K. C. \&Uzowuru, L. N. (2021).The effect of foreign portfolio investment on economic growth in Nigeria.South Asian Journal of Social Studies and Economics, 11(3), 43-53.

Lyndon, M. E., \&Ayaundu, E. S. (2020).An empirical evaluation of the effect of foreign investment inflows on economic growth in Nigeria.International Journal of Quantitative and Qualitative Research Methods, 8(1), $1-14$.

Okafor, E. I., Ezeaku, H. C. \&Eje, G. C. (2015). Foreign direct investment and its effect on the economic growth in Nigeria: A triangulation analysis. IOSR Journal of Economicsand Finance, 6(4/1), 1-7.

Onyeisi, O. S., Odo, I. S. \&Anoke, C. I. (2016). Foreign portfolio investment and stock market growth in Nigeria. Developing Country Studies, 6(11), 64-76.

Osmond, N. O. (2016). Foreign portfolio investment and industrial growth in Nigeria (1986-2013).International 
Journal of Innovative Finance and Economic Research, 4(3), 31-38.

Otapo, T. Y. \&Adekunle, O. E. (2020).Dynamic effects of foreign investment on economic growth in Nigeria.Financial Markets, Institutions and Risks, 4(3), 5-12.

Shamila, S,.Shujahat,. H. H., Muhammad, A. K. \& Muhammad, A. (2017). The impact of stock market performance on foreign portfolio investment inChina.International Journal of Economics and Financial Issues, 7(2), 460-468.

Tsaurai, K. (2017). Is foreign portfolio equty investment inspired growth hypothesis relevant in emerging markets? Euro Econometrica, 2(36), 78-90. World Development Indicator Database (2020). 